\title{
MARX PLURAL
}

\section{LUIZ ALFREDO GALVÃO}

Marx é plural e não singular. Quantos Marx existem? Na verdade, falar em Marx e Marx é insuficente; dever-se-ia falar em Marx \& Marx e Cia. No entanto, houve uma época em que, quando se falava em marxismo, entendia-se um sistema de idéias e uma concepção política de revolução socialista de modo claro e definido. Foi o período da Internacional Socialista. Havia unanimidade. A revolução social da clase operária só poderia ser o resultado do desenvolvimento máximo da sociedade capitalista industrial. Mesmo na Social-Democracia russa não se questionava esta concepção. Plekhánov, Mártov, Lenin, Trotsky, todos eles admitiam-na. Basta que se recorde o fato de que o marxismo revolucionário surge na Rússia contraposto ao populismo, que preconizava a revolução socialista num país atrasado, subdesenvolvido, semifeudal, pré-capitalista e pré-industrial, enquanto a social-democracia tinha como proposta a revolução democrática. O marxismo russo estava preso ao economicismo da problemática das forças produtivas. Inclusive a concepção de revolução permanente de Trotsky.

Para ele o proletariado, nas condições russas da revolução burguesa, poderia tomar o poder. O problema estava em como mantê-lo e construir o socialismo. Toda a questão da revolução permanente está explicitada da seguinte forma:

"A vitória da revolução somente será possível graças à conquista do poder revolucionário pelo proletariado. Esta revolução deixará de ser burguesa? Sim e não. Isto não depende de uma definição, mas do desenvolvimento ulterior dos acontecimentos. Se o proletariado for derrubado pela coalizão das classes burguesas, entre outras pelo campesinato que ele libertou, a revolução conservará seu caráter burguês. Mas se o proletariado for capaz de desenvolver todos os recursos de sua dominação política e se ele conseguir assim romper os quadros nacionais da revolução russa, esta se tornará o prólogo de um cataclisma mundial" (1905, Minuit, Paris, 1969, p. 367). 
O desenvolvimento da revolução vai depender, portanto, do poder proletário, o qual por sua vez vai se chocar com "uma grande dificuldade: o estado atrasado das condições econômicas do país. Nos limites de uma revolução nacional, esta situação não terá saída" (idem, p. 385).

Tudo depende do poder da classe operária e este está condicionado pelo desenvolvimento das forças produtivas. Eis a situação sem saída. A teoria da revolução permanente de Trotsky está montada num enorme condicional. O "se" da revolução permanente é a base material, que apenas a revolução nos países industrialmente desenvolvidos poderia fornecer.

Foi somente nos anos 20 que se começou a pôr em dúvida a "questão das forças produtivas", definida por Stalin (Problemas do Leninismo, 1924) como menchevismo. Aliás, não é sem razão que o trotskismo foi considerado como variante do menchevismo. Foi somente no período stalinista, com a estabilidade do capitalismo mundial e com a consolidação da ditadura bolchevique, que se começou a pôr em dúvida o fundamento materialista do socialismo científico.

Jamais Marx e Engels supuseram que a revolução socialista poderia se realizar com base no pré-capitalismo. Não tem cabimento imputar-lhes tal idéia. Basta que se recorde a sua prática política em 1848 para deixar patente tal "etapismo". E, em 1848, tratava-se de uma revolução em um país europeu - a Alemanha. Agora, se pensarmos na Ásia, África e América Latina, a possibilidade de revolução estava absolutamente afastada dos horizontes de Marx e Engels. Vejam-se, neste sentido, seus textos sobre a India e a China. Mas cono o marxismo conquistou o monopólio da idéia revolucionária, qualquer revolução - mesmo que seja a do agrarismo antiurbano do khmer rouge - se faz em nome de Marx.

Uma coisa é realizar um estudo objetivo das idéias de Marx, outra é querer encontrar nele idéias que justifiquem qualquer concepção de revolução. De fato, do ponto de vista do estrito marxismo (do materialismo histórico), a história do século XIX mostrou que o socialismo científico foi um fracasso, visto que o capitalismo foi capaz de continuar desenvolvendo as forças produtivas e que as relações capitalistas não se constituíram em um entrave à expansão econômica.

Julgar que a idéia de revolução permanente de Marx refere-se à revolução num país pré-capitalista é confundir o marxismo com o populismo (russo).

Michael Löwy (*) não é o único autor que quer adequar o marxismo aos problemas do século $\mathrm{XX}$ revendo as principais premissas

$\left(^{\circ}\right)$ Revolução Burguesa e Revolução Permanente em Marx e Engels, Revista Discurso n. ${ }^{\circ}$ 9, São Paulo, 1979. 
do materialismo histórico. Os marxismos de hoje pouco tềm a ver com o marxismo de Marx. Aliás, Sorel já dizia que o marxismo havia se tornado a grande desgraça do socialismo, porque a partir do seu monopólio ideológico a idéia da revolução passou a girar exclusivamente em torno de um só eixo doutrinário. Agora, continuamos a ter o mesmo pólo, porém com um número indeterminado de satélites: o marxismo alemão da Internacional Socialista, o austro-marxismo, o leninismo, o stalinismo, o trotskismo, o kruschevismo, o maoísmo, o guevarismo, o tupamarismo, o marighelismo, o marxismo islâmico, o das brigadas vermelhas etc.

Manobrar com a expressão "revolução permanente" para atribuir a Marx a idéia da possibilidade de revolução socialista em países précapitalistas pode ser programática e ideologicamente eficaz, mas não faz o menor sentido do ponto de vista da história das idéias políticás. A mais significativa referência de Marx à revolução permanente é a do programa da Liga Mundial dos Revolucionários Comunistas. No seu artigo $1 .^{\circ}$, encontramos o seguinte:

"Esta associação se propõe por finalidade a derrubada de todas as classes privilegiadas e a sua sujeição à ditadura dos proletários em que a revolução se manterá permanentemente até a implantação do comunismo, que será a última forma de vida da comunidade humana".

E de se notar que assinam tal documento, além de Marx, Engels e Willich pelos alemães, ainda Harney — o cartista radical, cujo inspirador era Babeuf - e os blanquistas franceses Adam e Vidil.

Da mesma época da Liga Mundial, temos também a referência de Marx à revolução permanente nas Lutas de Classe na França, onde se lê:

"O proletariado se agrupa mais e mais em torno do socialismo revolucionário, em torno do comunismo, para o qual a própria burguesia inventou o nome de Blanqui. Este socialismo é a declaração permanente da revolução, a ditadura de classe do proletariado, como ponto de transição necessário para chegar à supressão das diferenças de classe em geral."

Além da menção explícita a Blanqui e à união de Marx com os blanquistas, o que vemos nestes dois textos é a idéia de que a ditadura se manterá permanentemente até a consecução das finalidades últimas da revolução. E precisamente a forma sob a qual se manterá a ditadura do proletariado. 
Com relação ao autor da expressão "revolução permanente", esta ê uma questão que não nos deve preocupar. Trata-se de uma expressão que com toda a certeza foi usada pelos radicais jacobinos da revolução francesa - da mesma forma como foi vastamente usada, aqui no Brasil, por Médici, Geisel e Falcão - no sentido de que a revolução é permanente, isto é, de que o governo não abdicará do "direito revolucionário", do poder discricionário - fora da lei - do estado de sítio, e que não se submeterá ao Direito - não se constitucionalizará.

A expressão revolução permanente significa também que a revolução não é mais do povo ou do proletariado, mas do governo revolucionário - da ditadura. Quando na Mensagem de março de 1850 Marx lança a palavra de ordem "revolução permanente!", isto quer dizer apenas que o proletariado deve lutar para a instauração da ditadura, e que a ditadura se manterá permanentemente. O contexto de 1850 deixa claro que uma coisa é a revolução ininterrompida a passagem da revolução democrática à revolução proletária- e outra a revolução permanente, como forma da ditadura do proletariado.

Marx pode ser política e ideologicamente embaraçoso para quem quer encontrar nele a formulação plena das idéias humanas e libertárias. Depois da prática marxista do bolchevismo, o fato de que o marxismo original propõe a permanência da revolução por meio da ditadura não é algo que com facilidade pode ser apresentado publicamente - mas é um fato. Os textos de Marx aí estão; basta lêlos. Hoje, no entanto, ler Marx somente nos conduz a uma postura crítica. Mais do que em Marx, porém, os marxistas estão interessados na revolução, e em encontrar nele as idéias que justifiquem sua posição programática.

Ao escrever Marx \& Marx (*), eu sabia de boa parte das críticas de que seria alvo e me preocupei em respondê-las de antemão. Não contei, porém, com o fato de que o leitor marxista é por vezes desatento. Se Michael Löwy tivesse lido Marx \& Marx com atenção, saberia que a questão da "minoria esclarecida" em Marx foi analisada na II Parte do livro, onde se salientou precisamente este aspecto babovista-blanquista em Marx. E ainda, Michael Löwy ignora completamente a exaustiva discussão realizada na IV Parte sobre a con-

() Ed. Atica, São Paulo, 1977. 
cepção de Marx de "ditadura da burguesia". A partir do modo como foi usada a expressão "ditadura da burguesia" propus um conceito de ditadura de classe para Marx e o defini. Ora, foi a partir desta definição que concluí que "ditadura é um regime que, por definição, tem apenas um ou um número extremamente reduzido de homens na chefia do governo", e que se trata de um governo fora da lei.

Michael Löwy, porém, sugere que a ditadura pode ser exercida diretamente pela classe; mas sabemos que para Marx a "classe em si" nấo tem significado político nenhum. A classe só tem peso político como "classe para si", isto é, como organização - sindicato, partido (Miséria da Filosofia) ou mesmo o que viria a ser chamado de Estado operário. De tal sorte que a classe operária não é politicamente nada de modo imediato, só o é pela mediação da representação e da organização, e quem fala em representação e organização fala em minorias que têm a pretensão, como diz Marx no Manifesto Comunis$t a$, de "conhecer claramente os meios e os fins gerais do movimento". Deste modo, é da própria concepção política de classe em Marx que brota necessariamente a "minoria esclarecida".

Marx, no período de 1848 , faz muitas referências ao internacionalismo, mas ao mesmo tempo e prioritariamente luta para que "a Alemanha inteira (seja) declarada República una e indivisível". Se durante a revolução ele julgava que a burguesia podia realizar tal objetivo, depois da contra-revoluçẫo atribuiu ao proletariado da Alemanha tal missão. Não é preciso ser muito perspicaz para perceber que a palavra-de-ordem jacobina de "República una e indivisível" não se coaduna como meio para a internacionalização.

Na época da contra-revolução, Marx e Engels efetivamente perderam a serenidade e, em consequiência, se envolveram com os blanquistas e com os radicais da Liga dos Comunistas, deixando-se dominar por todos os seus desatinos. Quem formulou este juízo não foi o autor de Marx \& Marx, mas os próprios Marx e Engels. Michael Löwy mais uma vez não leu com atenção - no caso as páginas 159161; lá estão transcritos trechos da troca de correspondência entre Marx e Engels onde aparecem a amargura e o arrependimento de se terem envolvido pelo turbilhão e perdido a serenidade, no fogo da revolução (a contra-revolução é um momento da revolução e os primeiros meses do exílio em Londres não foram suficientes para esfriar o calor revolucionário).

Finalmente, deixando de lado agora a letra do texto e passando à sua significação mais geral, veremos que, ao final de Marx \& Marx, o que sobrou foi a dúvida. Se aceitarmos o materialismo histórico e a correspondente concepção de que a liberdade é a consciência da necessidade, teremos que questionar sobre esta necessidade. O socia- 
lismo científico é fruto da crítica do voluntarismo do socialismo utópico, e não faz nenhum sentido, nesta altura da vida, voltarmos ao utopismo pretendendo que a libertação seja uma práxis de auto-emancipação voluntária e consciente. Falar-se em dialética das condições objetivas e subjetivas absolutamente não resolve a questão. Se embarcamos na canoa do materialismo histórico temos de pensar nas leis, e, "mesmo que uma sociedade tenha descoberto a pista da lei natural que preside o seu movimento $(. .$.$) ela não pode ultrapassar$ cie um salto, nem abolir por decreto, as fases de seu desenvolvimento natural" (Prefácio de $O$ Capital). Hoje, depois da experiência histórica de outubro de 1917, sabemos que a liberdade não é um resultado natural e necessário da abolição da propriedade privada dos meios de produção, que a opressão já não decorre da propriedade burguesa, mas do Estado. É o próprio Estado operário que gera uma nova diferenciação social e uma nova forma de exploração. Mas também sabemos que as forças produtivas para se desenvolverem precisam de uma forma de propriedade mais ampla do que a burguesa, a substituição da economia de mercado pelo plano, e que é o plano que dará o poder e a força ao novo Leviatã.

Neste nosso final de século $\mathrm{XX}$, o socialismo já não nos permite mais ter a certeza ingênua do século passado na libertação. Do grande confronto entre o anarquismo e o marxismo, sobra-nos a melancólica conviç̧ão de que Marx tinha razão sobre Bakunin quando afirmava a necessidade econômica da estatização e da planificação; mas, por outro lado, a própria práxis do marxismo mostrou que também Bakunin tinha razão sobre Marx, quando dizia que, se fosse realizado o programa marxista de socialismo de Estado, surgiria uma nova classe dominante - a burocracia. 